\title{
Mode of overwintering of invasive Harmonia axyridis in the Netherlands
}

\author{
C. L. Raak-van den Berg • Lia Hemerik • \\ Peter W. de Jong $\cdot$ Joop C. van Lenteren
}

Received: 15 March 2011/Accepted: 4 July 2011/Published online: 11 August 2011

(C) The Author(s) 2011. This article is published with open access at Springerlink.com

\begin{abstract}
After establishment of Harmonia axyridis (Pallas) (Coleoptera: Coccinellidae) in Europe, population densities of native ladybird species have decreased. The post-hibernation onset of female reproduction, a key characteristic influencing population dynamics and competition with related species, was studied. Hibernating individuals were collected and transferred to outdoor cages to continue overwintering. Every two weeks a sample of individuals was transferred to long-day, warm conditions. Intensity of dormancy was studied by determining the pre-oviposition period and ovarian development. Preoviposition periods were short throughout our observations, indicating that Harmonia axyridis was not in diapause but in a quiescent state. $H$. axyridis becomes active rapidly when temperature rises in spring but is not active earlier in the year than native species. Neither the mode of overwintering, nor the onset of spring activity can explain the invasion success of H. axyridis.
\end{abstract}

Handling Editor: Patrick De Clercq

C. L. Raak-van den Berg ( $₫)$. P. W. de Jong .

J. C. van Lenteren

Laboratory of Entomology, Wageningen University, P.O. Box 8031, $6700 \mathrm{EH}$ Wageningen, The Netherlands e-mail: Lidwien.Raak-vandenBerg@wur.nl

L. Hemerik

Biometris, Wageningen University, Wageningen,

The Netherlands
Keywords Invasive species - Harmonia axyridis . Diapause $\cdot$ Hibernation $\cdot$ Pre-oviposition period . Semi-field experiment $\cdot$ Coleoptera $\cdot$ Coccinellidae

\section{Introduction}

The multicoloured Asian ladybird Harmonia axyridis Pallas (Coleoptera: Coccinellidae) was introduced as biological control agent in more than ten western European countries in the late 1990s (Brown et al. 2008). The introduction of $H$. axyridis is now considered an unfortunate event because of its negative side effects on, e.g., non-target species, fruit production, and human health (Koch 2003; van Lenteren et al. 2008; De Clercq and Bale 2011). Since 2002 H. axyridis has spread rapidly through Europe (Brown et al. 2008; Kenis et al. 2010), and it has currently established in 26 European countries and has been recorded in four other European countries (Brown et al. 2011b). The establishment of $H$. axyridis is associated with the decline of native coccinellid populations in urban, agricultural, and natural habitats in Europe (Adriaens et al. 2010; Brown et al. 2011a) and in North America (e.g., Michaud 2002; Alyokhin and Sewell 2004). Several mechanisms contribute to the rapid spread of $H$. axyridis and its effects on native species. Harmonia axyridis is a polyphagous species that feeds on numerous aphid species (Koch 2003) and other soft-bodied insects (Tedders and Schaefer 1994). As food sources of endemic ladybird species largely 
overlap with those of $H$. axyridis, the latter competes for food with many native coccinellid species (Lucas et al. 2007). Its polyphagous behaviour and aggressive nature also make it a strong intraguild predator (Pell et al. 2008) while its high fecundity (e.g., Hukusima and Kamei 1970; Wang et al. 2009) and low larval mortality (Dmitriew et al. 2009) can contribute to rapid population increase. The details of some of these traits and their exact contribution to the invasive success of $H$. axyridis still have to be unravelled, like those of another key biological characteristic of $H$. axyridis with consequences for population dynamics and interspecific competition: the speed with which it can start reproducing after winter dormancy.

Harmonia axyridis overwinters as adult in a state of dormancy. In the dormant state metabolism is greatly slowed down and development and reproduction are suppressed (Tauber et al. 1986; Denlinger 2002). Dormancy can occur in any season and in this state an organism is able to survive a period of unfavourable conditions, such as a prolonged period of low temperatures. In insects dormancy in winter is also called hibernation (Tauber et al. 1986; Gullan and Cranston 2005). In the majority of cases, insect dormancy is diapause-mediated: long before the onset of adverse conditions, the insects react to environmental cues and start a period of dormancy (Tauber et al. 1986). During diapause, several processes are arrested (e.g., growth and ovariole development), additional energy is stored (increase of fat bodies), and protected sites are sought (Tauber et al. 1986; Denlinger 2002). These modifications in physiology, morphology, and behaviour are called the 'diapause syndrome' and are species-specific (Tauber et al. 1986). Reproductive diapause describes the cessation or suspension of reproduction in mature insects (Gullan and Cranston 2005). When conditions temporarily improve, diapause persists. Diapause requires specific stimuli for termination (Gullan and Cranston 2005). However, no specific diapause-terminating stimulus has been identified for most temperatezone species that undergo an overwintering diapause (Tauber et al. 1986). In contrast, quiescence is a reversible state of very low activity and suppressed metabolism. Insects become quiescent when conditions become unfavourable. Quiescent insects remain highly responsive to changing environmental conditions and can immediately resume development or reproduction when favourable conditions return (Tauber et al. 1986; Gullan and Cranston 2005).
After diapause has been induced by environmental cues, the diapause state is intensified until all or most species-specific symptoms of diapause are present. Diapause progression continues with a gradual decrease in sensitivity to the diapause-maintaining stimuli resulting in a gradual termination of diapause. Insects may sometimes enter a state of post-diapause quiescence if they encounter unfavourable conditions after diapause termination. In this case, the characteristic diapause symptoms remain, but the insects are in a quiescent state and can react immediately when favourable environmental conditions develop. The developmental stage in which insects enter diapause is species-dependent (Tauber et al. 1986). In H. axyridis it is the adult stage.

Depending on the climate, overwintering of $H$. axyridis in the Northern Hemisphere takes place between October and April and lasts 3-6 months (Tanagishi 1976). Shortening of day length and a general decrease in temperature induces hibernation in H. axyridis (Tanagishi 1976; Sakurai et al. 1993). On clear, still, and relatively warm days, beetles start flying towards overwintering sites (Tanagishi 1976; Obata et al. 1986; Nalepa et al. 2005). These migratory flights often cover several kilometres (N. Osawa, personal communication, 2010) and are thought to be part of the 'diapause syndrome' (Tauber et al. 1986; Hodek et al. 1993; Hodek and Honek 1996).

The migratory flight of $H$. axyridis is directed by 'hypsotaxis': the beetles orient themselves towards the highest object on the horizon (Hagen 1962; Campan 1997). This can be a building, tower, pole, or anything else that forms a prominent, contrasting silhouette against the surrounding environment (Tanagishi 1976; Obata et al. 1986; Nalepa et al. 2005). At closer range alighting is stimulated by light colours (white and yellow) (Obata et al. 1986; Tedders and Schaefer 1994; Wang et al. 2011) and strongly contrasting lines (Nalepa et al. 2005). After landing, three types of behaviour can be distinguished (Tanagishi 1976; Nalepa et al. 2005): first, the beetles test whether the surface consists of an appropriate substrate; then they walk around in search of a local, dark site with an opening of at least $3 \mathrm{~mm}$ (Nalepa 2007); and finally they settle at those sites, where they form aggregations. In the final stage of the aggregation process the beetles appear to be influenced by volatiles emitted by conspecifics (Verheggen et al. 2007) and by faeces, residues, and dead beetles of the previous year 
(Tanagishi 1976; Nalepa et al. 2000). The ladybirds form clusters of up to several thousands of individuals in fairly exposed positions indoors, rendering overwintering a nuisance for house owners because of stains, smell, and allergic reactions (Koch 2003). In their native range the ladybirds leave the houses before the first frost and continue overwintering in mountain caves (Wang et al. 2011).

Despite the conspicuous migratory flights and the large clusters of beetles that are found in overwintering sites, few studies have focussed on the mode of overwintering of $H$. axyridis in the field, following cohorts throughout winter. Sakurai et al. (1992) indicated that overwintering of $H$. axyridis is diapause-regulated, since in their study ovaries remained undeveloped and corpora allata were small. In Europe hibernation of $H$. axyridis was studied by Iperti and Bertand (2001). Like Sakurai et al. (1992) they found that hibernating $H$. axyridis had enlarged fat bodies and poorly developed ovaries. Moreover, they found that $H$. axyridis entered hibernation with an empty gut. Berkvens et al. (2008) were able to induce a reproductive diapause in the fourth generation of a laboratory-reared population collected in the field in April 2005. However, they could not replicate this with individuals that were field-collected in June 2008 (Berkvens et al. 2010).

The current study was performed to shed light on the overwintering modes of the exotic, but established, ladybird $H$. axyridis in the Netherlands. The intensity of its dormancy was studied by determining the pre-oviposition period of hibernating field-collected individuals that were transferred to long-day conditions.

\section{Materials and methods}

\section{Sampling of Harmonia axyridis}

Hibernating adults of $H$. axyridis were collected from their hibernation sites at various locations in the Netherlands and at various dates during the winter of 2008-2009 (Table 1). After sampling the beetles were transported to Wageningen, The Netherlands in 11 jars with some wrinkled filter paper inside and covered with netting.
Effect of length of hibernation on pre-oviposition period

\section{Overwintering conditions of sampled beetles}

Overwintering beetles were kept at an experimental farm of Wageningen University. The jars with beetles were stored for about two weeks in an unheated shed under natural light conditions. During this storage period all beetles were counted in a climate room at $4^{\circ} \mathrm{C}$.

On 21 November 2008 the beetles were placed in flat cages behind wooden shutters $(120 \times 75 \times$ $3.5 \mathrm{~cm}$ ) mounted on the south-facing wall of the barn (Fig. 1). These cages consisted of wooden frames $(105 \times 60 \times 1.7 \mathrm{~cm})$ covered with netting made of PVC-coated fibre glass. Behind each shutter a single cage was mounted. The netting was fastened with magnetic strips and Velcro to enable easy access to the beetles. A strip of aluminium above the cages kept out most rain: the shutters became moist with heavy rain, but no wet beetles were observed.

Three of the shutters with cages were placed left of the barn entrance and three to the right (Fig. 1). Inside the barn was a cooling chamber with thick isolating walls positioned against the wall with the "right-side shutters", while a heater was located just at the inside of the wall that held the "left-side shutters".

The samples from Steinhull, Posbank and Lunteren were each put in individual cages. The Kootwijk sample was large and was divided over two cages. The samples collected in Deelen, Kop van Deelen, Loenen, and Alphen aan den Rijn were small and were combined in one cage.

All beetles were put in the cages on the same day and within a time span of $1 \mathrm{~h}$. Each cage contained between 1981 and 2527 beetles. In two cages (one at the left side and the other at the right side) data loggers (MicrologPRO, Fourier Systems) recorded temperature and humidity every half hour.

\section{Determination of the length of the pre-oviposition period}

Starting on 8 December 2008, samples of $40-60$ beetles were removed from each cage before noon at biweekly intervals and transferred to a climate chamber $\left(25^{\circ} \mathrm{C}, 16: 8 \mathrm{~L}: \mathrm{D}, 55 \pm 5 \mathrm{RH}\right)$, where sex 
Table 1 Sampling locations and -dates and, sample sizes of aggregated hibernating Harmonia axyridis adults in winter 2008-2009, the Netherlands

\begin{tabular}{|c|c|c|c|c|}
\hline Location & Coordinates $\left(\mathrm{DD}^{\circ} \mathrm{MM}^{\prime} \mathrm{SS}^{\prime \prime}\right)$ & Sampling date & Collection site & $\begin{array}{l}\text { Number of } \\
H \text {. axyridis } \\
\text { collected }\end{array}$ \\
\hline Deelen & $\begin{array}{l}\text { N } 52353 \\
\text { E } 55323\end{array}$ & 7 Nov 2008 & Outside: between wall and shutters & 719 \\
\hline Kop van Deelen & $\begin{array}{l}\text { N } 52337 \\
\text { E } 55354\end{array}$ & 7 Nov 2008 & Outside: between wall and shutters & 436 \\
\hline Posbank & $\begin{array}{l}\text { N } 52145 \\
\text { E } 6118\end{array}$ & 7 Nov 2008 & Outside: in folds of parasol & 2061 \\
\hline Alphen a/d Rijn & $\begin{array}{l}\text { N } 52727 \\
\text { E } 4402\end{array}$ & 11 Nov 2008 & Inside: unheated room & 547 \\
\hline Kootwijk & $\begin{array}{l}\text { N } 521039 \\
\text { E } 54539\end{array}$ & 13 Nov 2008 & $\begin{array}{l}\text { Outside: between wall and shutters } \\
\text { and between door and doorframe } \\
\text { Inside: unheated and heated rooms }\end{array}$ & $\begin{array}{r}4604 \\
242\end{array}$ \\
\hline Loenen, Ter Horst & $\begin{array}{l}\text { N } 52729 \\
\text { E } 6145\end{array}$ & 13 Nov 2008 & Inside: partly heated room & 398 \\
\hline Loenen, Steinhull & $\begin{array}{l}\text { N } 52622 \\
\text { E } 6023\end{array}$ & 13 Nov 2008 & $\begin{array}{l}\text { Outside: between wall and shutters } \\
\text { and in corners of window frames }\end{array}$ & 2530 \\
\hline Lunteren & $\begin{array}{l}\text { N } 52539 \\
\text { E } 5373\end{array}$ & 13 Nov 2008 & Inside: unheated attic & 1984 \\
\hline Experimental farm & $\begin{array}{l}\text { N } 515932 \\
\text { E } 53943\end{array}$ & $\begin{array}{l}28 \text { Nov } 2008 \\
30 \text { Mar } 2009^{a}\end{array}$ & $\begin{array}{l}\text { Overwintering in flat cages behind } \\
\text { shutters during experiment }\end{array}$ & 13521 \\
\hline
\end{tabular}

a After collection beetles continued overwintering at this location
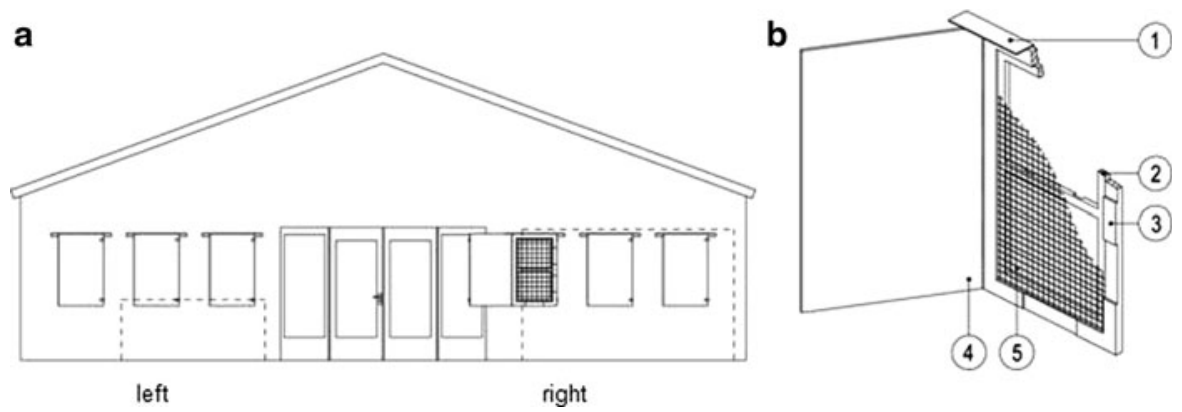

Fig. 1 a Outdoor cages for hibernation of Harmonia axyridis. Cages are mounted behind shutters on a south-facing wall of the farm building. The heating (left) and cooling chamber

(McCornack et al. 2007) and colour were determined, and five pairs (male and female) were isolated from each of those six samples. If there were not enough males in a sample from a particular cage, a male from a sample from another cage was used. If a male died before the end of the experiment, it was replaced with a male from the same cohort, originating from the same cage, if possible. Each pair was put in a $9 \mathrm{~cm}$ (right) inside the farm building are marked with dotted lines. b Detailed drawing of shutter with cage: 1 aluminium strip, 2 cage frame, 3 outer frame holding shutter, 4 shutter, 5 netting

diameter Petri dish lined with filter paper and provided with a mixed diet of frozen pollen, honey water $(10 \%)$ in a small Eppendorf tube stuffed with cotton wool, eggs of Ephestia kuehniella Zeller (Lepidoptera: Pyralidae), and live pea aphids (Acyrthosiphon pisum Harris (Hemiptera: Aphididae)). Every Monday and Wednesday new pollen, honey water, Ephestia eggs, and fresh aphids were added. 
Every Friday the beetles were transferred to clean Petri dishes and provided with fresh food. Pollen, honey water, and Ephestia eggs were given in excess.

The Petri dishes were checked daily for eggs. The pre-oviposition period was calculated as the number of days before oviposition of a cluster of fertile eggs. Eggs were separated from adults to avoid cannibalism and checked daily for hatching. A batch was considered hatched when neonate larvae had crawled out of their eggshells and were sitting on them or walking around. When the female did not start laying eggs within three weeks or when her eggs did not hatch, an extra male was added to check whether lack of oviposition was caused by female or by male sterility. The observation of a pair of beetles ended when the female died or when the first egg cluster hatched.

In early spring beetles started to mate and to move around in the outdoor cages, which indicated that their overwintering period had ended. At that moment the experiment was terminated and all beetles were removed from the cages. The last sampling was done on 30 March 2009.

Determination of ovary development during hibernation

In 2008, at each sampling date part of the beetles collected at Kootwijk and Steinhull were frozen for subsequent dissection and observation of ovarian development. In 2009 beetles were sampled at five locations (Alkmaar, Houten, Kootwijk, Steinhull, and Zundert) and continued overwintering at the experimental farm. Individuals were frozen for dissection at regular intervals. On the basis of earlier studies (El-Hariri 1966; Sakurai et al. 1986; Okuda and Hodek 1989; Phoofolo and Obrycki 1995; Iperti and Bertand 2001) five stages of ovarian development were distinguished (Table 2).

\section{Data analysis}

The data on the length of the pre-oviposition period were analysed using Cox's proportional hazards model (Yano et al. 2005). The model permits estimation of the period until a particular event is likely to occur, and the effects of various factors on the length of the period can be analysed as well. A unique aspect of Cox's model is that it also takes into account censored situations, i.e., situations where the experiment is ended while the event has not yet occurred.

Cox's model can be written as follows:

$h_{0}(t, Z)=h_{0}(t) \exp \left(\sum_{i=1}^{q} \beta_{i} z_{i}\right)$

where $h_{0}(t, Z)$ is the hazard rate (here: tendency to oviposit) at time $t$ with covariate values $Z\left(z_{i} ; i=1, \ldots\right.$, $q)$ based on a baseline hazard rate $h_{0}(t)$ and the regression coefficients $\beta_{\mathrm{i}}(i=1, \ldots, q)$ that give the relative contribution of the covariates.

The rate at which the event occurs, given that it has not happened up to that moment (time $t$ ), is called the hazard rate. Cox's model assumes a certain baseline hazard rate, multiplied by a factor that accounts for the effect of the covariates. So the hazard at time $t$ is expressed as a product of two quantities: the baseline hazard as a function of time and an exponential function involving fixed covariates. The main assumption of Cox's model is the proportional hazards assumption, meaning that the hazard rate of individuals with a certain covariate value is proportional to the hazard rate of individuals with another covariate value (Hemerik et al. 1993).

In this study, the event is the onset of oviposition after transfer of the beetles to warm, long-day conditions. If the female dies before oviposition, the observation is censored. The model assumes that the pre-oviposition period results from a basic oviposition tendency (i.e., the baseline hazard) and the effect of the covariate "time since the experiment started" representing the length of the overwintering period. Data were analysed using SPSS (version 15.0.1.1, July 2007).

\section{Results}

Effect of length of hibernation on pre-oviposition period

The pre-oviposition period of 272 pairs of $H$. axyridis was determined. At the last sampling occasion on 30 March 2009, one cage was sampled 5 h later than the other cages. Due to that delay, the beetles from that cage experienced more sunshine and a higher temperature than the other beetles. A preliminary analysis showed that this difference in treatment resulted in a significantly shorter pre-oviposition period and, 
Table 2 Developmental stages in ovarian development adapted after El-Hariri (1966), Sakurai et al. (1986), Okuda and Hodek (1989), Phoofolo and Obrycki (1995), and Iperti and Bertand (2001)

\begin{tabular}{|c|c|c|}
\hline $\begin{array}{l}\text { Ovary } \\
\text { stage }\end{array}$ & Description & Main characteristics \\
\hline 1 & No eggs present & $\begin{array}{l}\text { No eggs or follicles present in the ovarioles } \\
\text { No or hardly any constrictions of the ovarioles } \\
\text { No visible lighter coloured spots (indicating } \\
\text { follicles) }\end{array}$ \\
\hline 2 & one egg per ovariole, transparent & $\begin{array}{l}\text { First follicles are developing } \\
\text { Follicles are transparent/whitish } \\
\text { Ovarioles are constricted around the follicles }\end{array}$ \\
\hline 3 & 1-2 eggs per ovariole, yellow & $\begin{array}{l}\text { Each ovariole contains one or two eggs } \\
\text { Follicles become vitellinized/yellowish }\end{array}$ \\
\hline 4 & two eggs per ovariole, yellow & $\begin{array}{l}\text { Each ovariole contains two eggs } \\
\text { Follicles are vitellinized/yellow } \\
\text { Size of follicles increases }\end{array}$ \\
\hline 5 & $\begin{array}{l}\text { three mature eggs per ovariole, } \\
\text { yellow }\end{array}$ & $\begin{array}{l}\text { Each ovariole contains three mature eggs } \\
\text { Eggs are large and yellow }\end{array}$ \\
\hline
\end{tabular}

for this reason, the data of these five pairs were excluded from further analysis. Three further observations were excluded from the analyses, because the females died before any other female from the same sampling date had started oviposition. In total, 14 of the remaining $264(5.3 \%)$ pairs did not oviposit at all and were censored.

We observed that the temperature in cages behind shutters on the right side was on average $3.3^{\circ} \mathrm{C}$ higher than on the left side throughout the experiment (Fig. 2). This consistent temperature difference significantly influenced the pre-oviposition period (Logrank test, $\left.\chi_{1}^{2}=4.373, P=0.037\right)$. Beetles hibernating in the warmer left-side cages tended to start oviposition earlier than those in the colder right-side cages, but the effect was not proportional within the model.

To analyse the effect of the timing of subsample transfer to long-day conditions on the pre-oviposition period, we used a stratified Cox's model to include this non-proportional temperature effect of left and right-side cages. The timing of subsample removal did not affect the length of the pre-oviposition period, and the effect was not proportional within the model. Figure 3 shows the median pre-oviposition period for each sampling moment, stratified for left and right. Based on this preliminary analysis the sampling moments were grouped into three periods with different responses: (1) short dormancy period: hibernation up to 5 January at the latest; (2) medium dormancy period: hibernation up to 19 January at the



Fig. 2 Average daily temperature recorded in the cages

earliest and up to 16 February at the latest; (3) long dormancy period: hibernation up to 2 March at the earliest and up to 30 March at the latest. The effect of the length of the dormancy period was tested with a Cox's regression model stratified for left and right cages.

The length of the dormancy period significantly influenced the pre-oviposition period (Cox's regression Wald test $=96.450$, df $=2, P<0.001$ ). Beetles with a long dormancy period started oviposition after five days (median) regardless of whether they had hibernated on the left or right-side. Beetles with a short dormancy period had a median pre-oviposition period of nine (left) and ten days (right). For beetles 

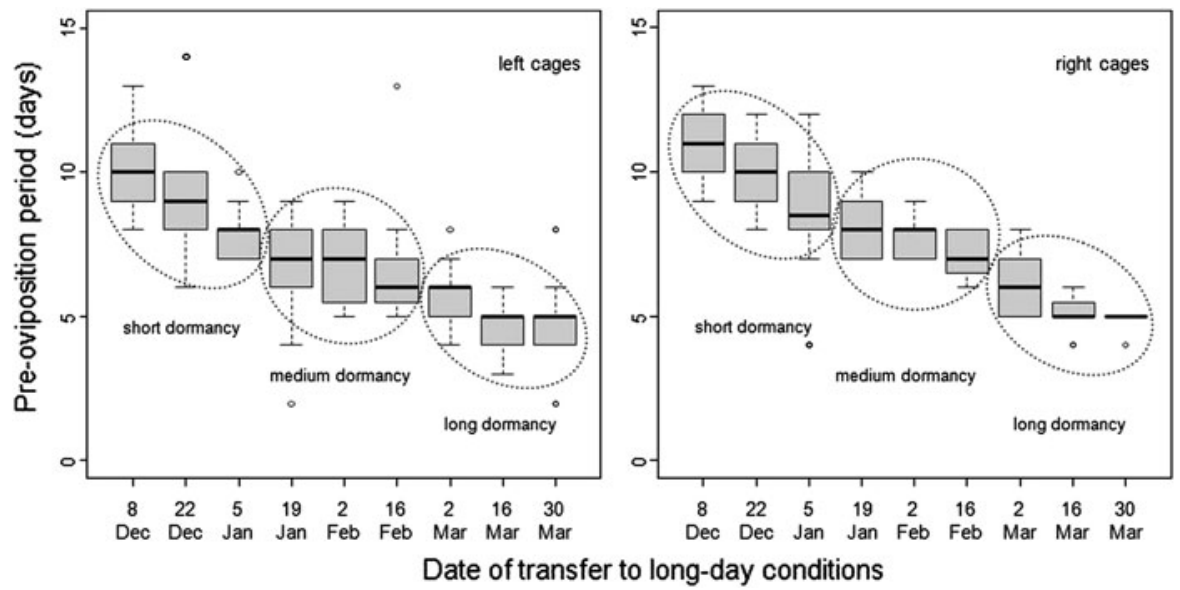

Fig. 3 Median pre-oviposition period of $H$. axyridis females after transfer from outdoor hibernation cages to long-day conditions $\left(25^{\circ} \mathrm{C}, 16: 8 \mathrm{~L}: \mathrm{D}\right)$. The pre-oviposition periods are grouped based on the length of the hibernation period of the beetles. The boxes represent the first to third quartile range with the median indicated by a line across the box. The whiskers represent roughly a 95\% confidence interval for the difference between two medians. Outliers, which are all censored observations are presented by open circles, some (six for left cages and five for right cages) lie outside the plot range and are not shown
Fig. 4 Fraction of nonovipositing females of $H$. axyridis over time after transfer from outdoor hibernation cages to longday conditions $\left(25^{\circ} \mathrm{C}, 16: 8\right.$ L:D). The data are grouped on the basis of the length of the hibernation period of the beetles (see text) and stratified for cages on the left and right side
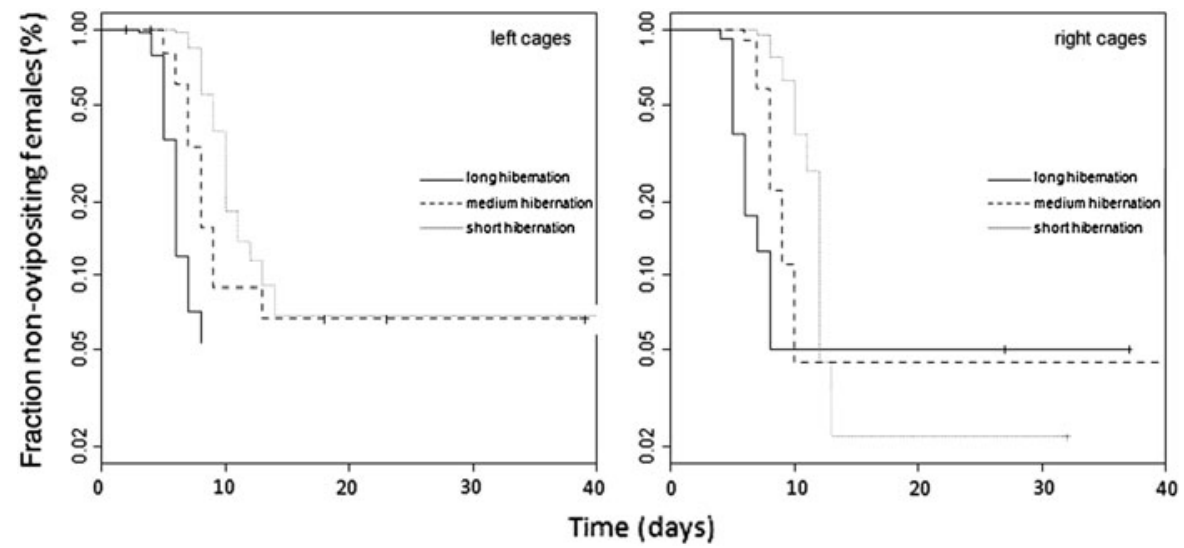

with a medium dormancy period the median preoviposition period was seven (left) and eight days (right) (Fig. 4). Colour morph did not significantly influence the pre-oviposition period.

Cox's model determines a hazard rate for all values of the categorical covariate (length of the dormancy period) for both strata (left and right). In this study the hazard rate was 'the oviposition tendency' i.e., the probability per time unit that a female started to lay eggs, when oviposition had not yet started. The oviposition tendency increased when the dormancy period was longer.

The hazard ratio between beetles with long and short dormancy periods was 5.38, and that between beetles with medium versus short dormancy was 1.95 . This means that the tendency to begin oviposition at any point in time once transferred to long-day conditions was almost twice as large for medium-dormancy individuals as for short-dormancy individuals and more than five times as large for long-dormancy individuals.

Determination of ovary development during hibernation

In total 214 of the frozen beetles of the 2008-2009 winter were dissected, 157 of which were female. Only four beetles, sampled on 30 March 2009, 
showed some restriction of the ovaries (Table 2). These ovaries were still in stage 1 of ovarian development, as the restriction was not visible in all ovarioles and no follicle development could be seen. During the 2009-2010 winter, 436 beetles were dissected, of which 266 were female. Three beetles, sampled on 29 March 2010, showed restriction in some of the ovarioles and were in stage 1 of ovarian development. One beetle, sampled on 29 March 2010, showed ovarian developmental stage 2.

\section{Discussion}

Diapause and/or quiescence?

Many studies have been conducted to unravel the mechanics of dormancy (see Tauber et al. 1986), and a number of studies has been done to determine whether H. axyridis shows diapause or quiescence (Sakurai et al. 1992; Ongagna and Iperti 1994; Iperti and Bertand 2001; Berkvens et al. 2008). The results of these studies are not always consistent, and some are even contradictory, which we will illustrate below.

Insects in reproductive diapause will not react to an improvement of weather conditions by laying eggs, whereas insects that are in a quiescent state will start oviposition after transfer to favourable conditions. The intensity and development of the diapause can be estimated by the duration of the pre-oviposition period. Emerging adults of the $H$. axyridis summer generation show a pre-oviposition period of 5.25-11.5 days with a weighted average of 7.96 days when determined at $25^{\circ} \mathrm{C}$, long-day conditions and with provision of prey (Table 3). Compared to this, a pre-oviposition period that is at least twice as long can be considered as a sign of delayed oviposition due to diapause, according to Obrycki et al. (1983) and Hodek et al. (1989).

Two observations suggest that $H$. axyridis overwinters in reproductive diapause in the Netherlands. Firstly, in the current study the ovaries were regressed during the whole winter, like the ovaria of hibernating females in Japan (Sakurai et al. 1992). They concluded that Japanese H. axyridis show true diapause because reproduction was completely suppressed, the corpus allatum was atrophied, and adults had a developed fat body.
Secondly, hibernation of $H$. axyridis is characterised by typical migration behaviour (Obata et al. 1986; Nalepa et al. 2005). In the Netherlands these migratory flights took place at the end of October in 2008. As $H$. axyridis arrives at its overwintering site long before true winter conditions set in, this behaviour could be seen as part of the diapause syndrome as defined by Tauber et al. (1986) and would indicate that $H$. axyridis enters diapause in the Netherlands at the end of October. Moreover two studies have been conducted where diapause could be induced in $H$. axyridis: in a population reared under outdoor conditions in southern France (Ongagna and Iperti 1994) and in a population reared in the laboratory for four generations in Belgium (Berkvens et al. 2008).

In contrast to the above-mentioned information indicating existence of a reproductive diapause, the pre-oviposition periods of beetles transferred to longday conditions in our study indicate lack of a reproductive diapause as they were evenly distributed around the mean and could not be separated into an early ovipositing group and a late ovipositing group as found in studies by Obrycki et al. (1983). The median pre-oviposition period of adults sampled on 8 December 2008 was ten days. This falls within the range of the normal pre-oviposition period of the summer population (Table 3), suggesting that $H$. axyridis was not in diapause in early December. Moreover, the adults also reacted to favourable conditions with a rapid resumption of oviposition. Thus, our finding of short pre-oviposition periods for beetles transferred from the field to warm laboratory conditions on 8 December seems to point towards quiescence rather than diapause. The explanation for these apparently contradictory observations might be that $H$. axyridis is only in diapause for a short period. If diapause of $H$. axyridis has a maximum duration of one month, beetles in the current study would have completed their diapause by the beginning of December and would already have shifted to a state of quiescence by the time the first sample to determine the pre-oviposition period was taken. This hypothesis is supported by Berkvens et al. (2008), who found that it took aphid-fed adults from the fourth laboratory generation about one month to start oviposition under short-day (12:12 L:D) but warm $\left(23^{\circ} \mathrm{C}\right)$ conditions. 
Table 3 Pre-oviposition periods of emerging adult Harmonia axyridis determined at $25^{\circ} \mathrm{C}$ and under long-day conditions

\begin{tabular}{lllll}
\hline $\begin{array}{l}\text { Pre-oviposition period } \\
\text { mean/median days }( \pm \mathrm{SD}) \text { [range] }\end{array}$ & Population & Photoperiod (L:D) & $\mathrm{N}$ & Study \\
\hline $10.1^{\mathrm{a}}$ & Field & Natural day length & 6 & Hukusima and Kamei (1970) \\
$11.5^{\mathrm{a}}$ & Field & Natural day length & 13 & Hukusima and Kamei (1970) \\
$7.4[6-10]^{\mathrm{b}}$ & Laboratory & $16: 8$ & 15 & Lanzoni et al. (2004) \\
$9.8( \pm 1.3)^{\mathrm{c}}$ & Laboratory & $16: 8$ & 20 & Schanderl et al. (1988) \\
$10[7-20]^{\mathrm{d}}$ & Laboratory & $16: 8$ & 16 & Seko and Miura (2009) \\
$7.5[4-17]^{\mathrm{d}}$ & Laboratory & $16: 8$ & 24 & Seko and Miura (2009) \\
$7.2( \pm 1.12)^{\mathrm{c}}$ & Laboratory & $16: 8$ & 30 & Stathas et al. (2001) \\
$5.25( \pm 0.87)^{\mathrm{c}}$ & Laboratory & $16: 8$ & 24 & Pers. comm. G.J. Stathas \\
$7.92( \pm 1.62)^{\mathrm{c}}$ & Laboratory & $16: 8$ & 24 & Pers. comm. G.J. Stathas \\
$7.3( \pm 0.7)^{\mathrm{c}}$ & Field & $14: 10$ & 30 & Wang et al. (2009) \\
\hline
\end{tabular}

Beetles were provided with a surplus of prey

${ }^{\mathrm{a}}$ mean; ${ }^{\mathrm{b}}$ mean [range]; ${ }^{\mathrm{c}}$ mean $( \pm \mathrm{SD}) ;{ }^{\mathrm{d}}$ median [range]

Berkvens et al. (2008) also showed that diet influences the pre-oviposition period. Females fed with Ephestia eggs had a pre-oviposition period twice as long as that of females fed with aphids (A. pisum). A. pisum is a natural prey for $H$. axyridis, whereas Ephestia eggs are factitious prey (Hodek and Honek 1996). Factitious prey is reported to act as a diapauseinducing and diapause-maintaining stimulus (Hodek 1983). In the current study field-collected adults were used, that were fed both aphids (A. pisum) and Ephestia eggs, so we did not expect a delay in egg laying due to a lack of optimal food.

Iperti and Bertand (2001) showed that hibernating adults in the mountains of south-eastern France, after transfer to long-day conditions $\left(16: 8 \mathrm{~L}: \mathrm{D}\right.$, at $\left.22^{\circ} \mathrm{C}\right)$, had a pre-oviposition period that shortened from January onwards. They concluded that $H$. axyridis was in a state of quiescence from that month onwards. The long pre-oviposition period of on average 16 days after transfer in December might indicate that these beetles were still in diapause. The pattern of one month of diapause and a switch to quiescence seems similar for the south-eastern French and the Dutch populations, which can be explained by similar temperatures in south-eastern France and the Netherlands during the study period. The longterm average temperature in south-eastern France (Antibes) in November is $\min 8.7^{\circ} \mathrm{C}$ and $\max 16.3^{\circ} \mathrm{C}$ (Météo France 2010) while in the Netherlands in October 2008 the minimum temperature is $6.8^{\circ} \mathrm{C}$ and the maximum temperature $13.9^{\circ} \mathrm{C}$ (KNMI 2010).
Although the average temperatures during winter are higher in south-eastern France than in the Netherlands, these higher temperatures did not stimulate spring emergence to occur earlier than in the Netherlands.

At this state of our knowledge, we conclude that in the Netherlands, and perhaps more generally in western Europe, and maybe even in the area of origin of this species, $H$. axyridis enters a period of diapause of about one month. It shows characteristic migration and overwintering-site-selection behaviour before the start of winter and has undeveloped ovaries. In December diapause is complete, but oviposition does not occur because it is too cold for the beetles to feed and develop their ovaries. In the beach leaf mining weevil Rhynchaenus fagi L. (Curculionidae, Coleoptera) a similar mechanism has been observed (Bale 1979). In this study diapause ended in November/December, and post-diapause low temperatures actually produced the observed synchrony of emergence from hibernation and the budding of new leaves, rather than diapause being a synchronising mechanism between development and food availability. In the flesh fly Sarcophaga bullata Parker (Diptera: Sacrophagidae) too, pupal diapause is completed by the end of December while the low temperatures of the ensuing winter months suppress development and provide a synchronisation mechanism for uniform development when the developmental temperature threshold is reached in early April (Denlinger 1972). 
Table 4 Developmental thresholds ( \pm SE when available in original paper) for Adalia bipunctata, Coccinella septempunctata, Harmonia axyridis, and Hippodamia convergens

\begin{tabular}{lllll}
\hline Species & \multicolumn{2}{l}{ Lower developmental threshold $\left({ }^{\circ} \mathrm{C}\right)$} & & Study \\
\cline { 2 - 5 } Egg & $\begin{array}{l}\text { Pre- } \\
\text { oviposition }\end{array}$ & Oviposition & $\begin{array}{l}\text { Post- } \\
\text { diapause } \\
\text { development }\end{array}$ & $\begin{array}{l}\text { Predation } \\
\text { activity }\end{array}$ \\
\hline
\end{tabular}

\section{A. bipunctata}

A. bipunctata

A. bipunctata

$9.2 \pm 1.2$

A. bipunctata

8.2

A. bipunctata

10.5

A. bipunctata

A. bipunctata

C. septempunctata

C. septempunctata

10.2

C. septempunctata

C. septempunctata

C. septempunctata

C. septempunctata

C. septempunctata

C. septempunctata

C. septempunctata bruckii

C. septempunctata bruckii

H. axyridis

H. axyridis

H. axyridis

H. axyridis

H. axyridis

H. axyridis

H. axyridis

$H$. axyridis aulica adult

H. axyridis nigra

adult

H. axyridis aulica larvae

H. axyridis nigra

larvae

$H$. convergens

$H$. convergens

$H$. convergens

H. convergens

$H$. convergens

H. convergens

H. convergens

11.7

$6.8 \pm 0.6$

$9.2 \pm 1.4$

13.2

13.6

11.1

$9.7 \pm 1.2$

10.1

$9.5 \pm 0.3$
6.8

$10.9 \pm 0.6$

17.5

$\begin{array}{ll}9.76 & \\ 10.7 & \\ 11 \pm 0.2 & \\ 10.2 \pm 1.6 & 10.8 \pm 1.7 \\ 11.4 \pm 0.7 & 12.0 \pm 2.6 \\ & 11.3\end{array}$

9.3

10.4

10.4

$11.7 \pm 0.9$

$11.3 \pm 1.11$
Obrycki and Tauber (1981)

Sakuratani et al. (2000)

Honek and Kocourek (1988)

Hämäläinen and Markkula (1977)

in Hodek and Honek (1996)

Frazer and McGregor (1992)

Obrycki et al. (1983)

Honek and Kocourek (1988)

Hämäläinen and Markkula (1977)

in Hodek and Honek (1996)

Xia et al. (1999)

Hodek et al. (1958) in Honek

and Kocourek (1988)

Obrycki and Tauber (1981)

Frazer and McGregor (1992)

Butler (1982) in Hodek and Honek (1996)

Butler (1982) in Hodek and Honek (1996)

Kawauchi (1983)

Wang et al. (2009)

Schanderl et al. (1985)

Lamana and Miller (1998)

Pers. comm. G.J. Stathas

Pers. comm. G.J. Stathas

Stathas et al. (2001)

Soares et al. (2003)

Soares et al. (2003)

Soares et al. (2003)

Soares et al. (2003)

Obrycki and Tauber (1982)

Butler and Dickerson (1978)

in Honek and Kocourek (1988)

Frazer and McGregor (1992)

Miller (1992)

Miller (1992)

Michaud and Qureshi (2006)

Predation activity indicates the threshold for predatory activity. Thresholds have not been recalculated by the authors. Data from original study or from paper referring to the original data are given 
As a result of a quite late start of the determination of reproduction, we measured the intensity of quiescence and the rate at which the beetles start reproduction after hibernation periods of different lengths rather than the depth of diapause. Determination of the pre-oviposition period during the month of supposed diapause is necessary to further support our hypothesis that $H$. axyridis shows a diapause of one month, followed by quiescence.

Diapause and quiescence in other ladybird beetles

Research with other ladybird species has been conducted in a way comparable to the present study. Obrycki et al. (1983) transferred Adalia bipunctata L. (Coleoptera: Coccinellidae) females from the field to several photoperiods in the laboratory. In October these females started laying eggs within 15 days under long-day conditions (16:8 and 14:10), whereas under short-day conditions it took more than 75 days to start oviposition. Transfer in December resulted in an average pre-oviposition period of 10.8 days at the 14:10 photoperiod. At a short-day photoperiod some individuals started laying eggs within 30 days, while others showed a pre-oviposition period of more than 90 days. In March all females oviposited within 12 days regardless of the photoperiod. This study showed that in A. bipunctata long day length can terminate diapause in the laboratory, while short day length maintains diapause. The study also showed that in December the response to photoperiod had already diminished substantially, but that the beetles remained sensitive to a diapause maintaining photoperiod (Obrycki et al. 1983).

Hodek and co-workers sampled Coccinella septempunctata L. (Coleoptera: Coccinellidae) from hibernation quarters and transferred the beetles to long-day and short-day conditions. The difference in pre-oviposition period for the different photoperiods was large in October, while in December it could only be found in a part of the population, and in May it did no longer exist (Hodek et al. 1977; Hodek and Ruzicka 1979). In contrast, hibernating C. septempunctata populations from Greece and Spain did not show any response to photoperiod as the preoviposition period was similar under long-day and short-day conditions (Hodek et al. 1989; Hodek and Okuda 1993).
Our study shows that $H$. axyridis can rapidly become active when temperature rises. Thus, the start of reproduction and the rate of population growth of $H$. axyridis in spring will mainly be influenced by the availability and quality of prey and not by the mode of overwintering. Since $H$. axyridis is a polyphagous species, it is not dependent on the availability of a single prey species but can use many different kinds of prey that are available early. One could argue that this is an advantage over native species as it may contribute to rapid population growth. However, a comparison with the lower developmental thresholds of A. bipunctata, C. septempunctata, and Hippodamia convergens Guérrin-Méneville (Coleoptera: Coccinellidae) shows that the thresholds of $H$. axyridis are similar to those of $C$. septempunctata and $H$. convergens (Table 4). The thresholds of $A$. bipunctata are even lower than those of H. axyridis. Moreover, phenological data from Belgium, the UK, and the Netherlands do not suggest that $H$. axyridis is active earlier than the other species (Adriaens et al. 2008; Waarneming.nl 2010; Brown et al. 2011a). Thus, neither the mode of overwintering nor the moment that adult beetles become active in spring can explain the invasion success of $H$. axyridis. We are presently studying overwintering mortality and interspecific competition behaviour of $H$. axyridis in order to find explanations for its quick establishment and large population growth in the Netherlands.

Acknowledgments The following people have contributed to this study J. Abma, Mr \& Mrs Brandsma, A.B. Allema, S.W. Benedictus-van den Berg, C.A.J.M. van Boxel, T. Bukhari, I. Folkertsma, Mr \& Mrs Huijsman, Y. Jongema, Mr \& Mrs van der Kamp, Mr \& Mrs Klok, A.J.M. Loomans, K. Oku, D. Lucas-Barbosa, G. Mekking, Paviljoen de Posbank, Profict, Y.T. Qiu, M.J. Raak, S.E. Raak, H. van Roekel, A. Siepel, and W. van Tol. We thank three anonymous reviewers for constructive comments on an earlier version of the manuscript.

Open Access This article is distributed under the terms of the Creative Commons Attribution Noncommercial License which permits any noncommercial use, distribution, and reproduction in any medium, provided the original author(s) and source are credited.

\section{References}

Adriaens T, Gomez GMY, Maes D (2008) Invasion history, habitat preferences and phenology of the invasive ladybird Harmonia axyridis in Belgium. BioControl 53:69-88 
Adriaens T, San Martin G, Branquart E, Maes D (2010) Towards a Noahs Ark for native ladybird in Belgium? In: Babendreier D, Aebi A, Kenis M and Roy HE (eds). IOBC/WPRS Bulletin, pp 1-3

Alyokhin A, Sewell G (2004) Changes in a lady beetle community following the establishment of three alien species. Biol Invasions 6:463-471

Bale JS (1979) The occurrence of an adult reproductive diapause in the univoltine life cycle of the beech leaf mining weevil, Rhynchaenus fagi L. Int J Invertebr Reprod 1:57-66

Berkvens N, Bonte J, Berkvens D, Tirry L, De Clercq P (2008) Influence of diet and photoperiod on development and reproduction of European populations of Harmonia axyridis (Pallas) (Coleoptera: Coccinellidae). BioControl 53:211-221

Berkvens N, Bale JS, Berkvens D, Tirry L, De Clercq P (2010) Cold tolerance of the harlequin ladybird in Europe. J Insect Physiol 56:438-444

Brown PMJ, Adriaens T, Bathon H, Cuppen J, Goldarazena A, Hagg T, Kenis M, Klausnitzer BEM, Kovar I, Loomans AJM, Majerus MEN, Nedved O, Pedersen J, Rabitsch W, Roy HE, Ternois V, Zakharov IA, Roy DB (2008) Harmonia axyridis in Europe: spread and distribution of a non-native coccinellid. BioControl 53:5-21

Brown PMJ, Frost R, Doberski J, Sparks T, Harrington R, Roy HE (2011a) Decline in native ladybirds in response to the arrival of Harmonia axyridis: early evidence from England. Ecol Entomol 36:231-240

Brown PMJ, Thomas CE, Lombaert E, Jeffries DL, Estoup A, Lawson Handley LJ (2011b) The global spread of Harmonia axyridis (Coleoptera: Coccinellidae): distribution, dispersal and routes of invasion. BioControl. doi: 10.1007/s10526-011-9379-1

Campan R (1997) Tactic components in orientation. In: Lehrer $\mathrm{M}$ (ed) Orientation and communication in arthropods. Birkhaeuser, Basel, pp 1-40

De Clercq P, Bale JS (2011) Risks of invertebrate biological control agents: Harmonia axyridis as a case study. In: Ehlers R-U (ed) Regulation of biological control agents. Springer, Dordrecht, pp 243-255

Denlinger DL (1972) Seasonal phenology of diapause in the flesh fly Sarcophaga bullata. Ann Entomol Soc Am 65: 410-414

Denlinger DL (2002) Regulation of diapause. Annu Rev Entomol 47:93-122

Dmitriew C, Carroll J, Rowe L (2009) Effects of early growth conditions on body composition, allometry, and survival in the ladybird beetle Harmonia axyridis. Can J Zool 87:175-182

El-Hariri G (1966) Studies of the physiology of hibernating Coccinellidae (Coleoptera): changes in the metabolic reserves and gonads. Proc R Ent Soc Lond 41:133-144

Frazer BD, McGregor RR (1992) Temperature-dependent survival and hatching rate of eggs of seven species of Coccinellidae. Can Entomol 124:305-312

Gullan PJ, Cranston PS (2005) The insects: an outline of entomology. Blackwell Science, Oxford

Hagen KS (1962) Biology and ecology of predaceous Coccinellidae. Annu Rev Entomol 7:289-326
Hemerik L, Driessen G, Haccou P (1993) Effects of intra-patch experiences on patch time, search time and searching efficiency of the parasitoid Leptopilina clavipes. J Anim Ecol 62:33-44

Hodek I (1983) Role of environmental factors and endogenous mechanisms in the seasonality of reproduction in insects diapausing as adults. Dr W Junk Publishers, The Hague, pp 9-33

Hodek I, Honek A (1996) Ecology of Coccinellidae. Kluwer, Dordrecht

Hodek I, Okuda T (1993) A weak tendency to "obligatory" diapause in Coccinella septempunctata from southern Spain. Entomophaga 38:139-142

Hodek I, Ruzicka Z (1979) Photoperiodic response in relation to diapause in Coccinella septempunctata (Coleoptera). Acta Entomol Bohemoslov 76:209-218

Hodek I, Iperti G, Rolley F (1977) Activation of hibernating Coccinella septempunctata (Coleoptera) and Perilitus coccinellae (Hymenoptera) and the photoperiodic response after diapause. Entomol Exp Appl 21:275-286

Hodek I, Hodkova M, Sem'yanov VP (1989) Physiological state of Coccinella septempunctata adults from northern Greece sampled in mid-hibernation. Acta Entomol Bohemoslov 86:241-251

Hodek I, Iperti G, Hodkova M (1993) Long-distance flights in Coccinellidae (Coleoptera). Eur J Entomol 90:403-414

Honek A, Kocourek F (1988) Thermal requirements for development of aphidophagous Coccinellidae (Coleoptera), Chrysopidae, Hemerobiidae (Neuroptera), and Syrphidae (Diptera): some general trends. Oecologia 76: 455-460

Hukusima S, Kamei M (1970) Effects of various species of aphids as food on development, fecundity and longevity of Harmonia axyridis Pallas (Coleoptera: Coccinellidae). Res Bull Fac Agric Gifu Univ 29:53-66

Iperti G, Bertand E (2001) Hibernation of Harmonia axyridis (Coleoptera: Coccinellidae) in South-Eastern France. Acta Soc Zool Bohem 65:207-210

Kawauchi SE (1983) The threshold temperature and thermal constant for development from the egg to the adult form of Coccinella septempunctata brucki, Propylea japonica and Scymnus (Pullus) hoffmanni (Coleoptera, Coccinellidae). Kurume Univ J 32:45-51

Kenis M, Brown P, Ware R, Roy DB (2010) Invasion of the Harlequin ladybird, Harmonia axyridis, in Europe: when beauty becomes the beast. In: Settele J, Penev LD, Georgiev TA, Grabaum R, Grobelnik V, Hammen V, Klotz S, Kotarac M and Kuehn I (eds) Atlas of biodiversity risks. Pensoft Publishers, Sofia, pp 40-41

KNMI (2010) Maand- en jaarwaarden van de temperatuur, neerslag en luchtdruk De Bilt. In: Koninklijk Nederlands Meteorologisch Instituut. http://www.knmi.nl/klimatologie/ maandgegevens/index.html Accessed: 25 November 2010

Koch RL (2003) The multicolored Asian lady beetle, Harmonia axyridis: a review of its biology, uses in biological control, and non-target impacts. J Insect Sci (Tucson) 3:1-16

LaMana ML, Miller JC (1998) Temperature-dependent development in an Oregon population of Harmonia axyridis (Coleoptera: Coccinellidae). Environ Entomol 27: 1001-1005 
Lanzoni A, Accinelli G, Bazzocchi GG, Burgio G (2004) Biological traits and life table of the exotic Harmonia axyridis compared with Hippodamia variegata, and Adalia bipunctata (Col., Coccinellidae). J Appl Entomol 128:298-306

Lucas E, Labrie G, Vincent C, Kovach J (2007) The multicoloured Asian ladybird beetle: beneficial or nuisance organism? In: Vincent C, Goettel MS, Lazarovits G (eds) Biological control: a global perspective. CABI, Wallingford, pp 38-52

McCornack BP, Koch RL, Ragsdale DW (2007) A simple method for in-field sex determination of the multicolored Asian lady beetle Harmonia axyridis. J Insect Sci 7:12

Météo France (2010) Moyennes mensuelle Nice. In: Météo France. http://climat.meteofrance.com/chgt_climat2/ climat_france Accessed: 1 December 2010

Michaud JP (2002) Invasion of the Florida citrus ecosystem by Harmonia axyridis (Coleoptera: Coccinellidae) and asymmetric competition with a native species, Cycloneda sanguinea. Environ Entomol 31:827-835

Michaud JP, Qureshi JA (2006) Reproductive diapause in Hippodamia convergens (Coleoptera: Coccinellidae) and its life history consequences. Biol Control 39:193-200

Miller JC (1992) Temperature-dependent development of the convergent lady beetle (Coleoptera: Coccinellidae). Environ Entomol 21:197-201

Nalepa CA (2007) Harmonia axyridis (Coleoptera: Coccinellidae) in buildings: relationship between body height and crevice size allowing entry. J Econ Entomol 100:1633-1636

Nalepa CA, Kidd KA, Hopkins DI (2000) The multicolored Asian lady beetle (Coleoptera: Coccinellidae): orientation to aggregation sites. J Entomol Sci 35:150-157

Nalepa CA, Kennedy GG, Brownie C (2005) Role of visual contrast in the alighting behavior of Harmonia axyridis (Coleoptera: Coccinellidae) at overwintering sites. Environ Entomol 34:425-431

Obata S, Johki Y, Hidaka T (1986) Location of hibernation sites in the ladybird beetle, Harmonia axyridis. Conference: Ecology of aphidophaga: proceedings of the 2nd symposium, Zvikovske, Podhradi, pp 193-198

Obrycki JJ, Tauber MJ (1981) Phenology of 3 coccinellid species (coleoptera, coccinellidae) Adalia bipunctata, Coccinella transvergotta, Coccinella septempunctata: thermal requirements for development. Ann Entomol Soc Am 74:31-36

Obrycki JJ, Tauber MJ (1982) Thermal requirements for development of Hippodamia convergens (Coleoptera, Coccinellidae). Ann Entomol Soc Am 75:678-683

Obrycki JJ, Tauber MJ, Tauber CA, Gollands B (1983) Environmental control of the seasonal life cycle of Adalia bipunctata (Coleoptera: Coccinellidae). Environ Entomol 12:416-421

Okuda T, Hodek I (1989) Flight tendency of 2 coccinellids, Semiadalia undecimnotata and Coccinella septempunctata, in relation to diapause. In: Anon (ed) Regulation of insect reproduction. Proceedings of a symposium held in Zinkovy, September 1987. Academia Publishing House, Czechoslovak Academy of Science, Prague, pp 385-400

Ongagna P, Iperti G (1994) Influence of temperature and photoperiod in Harmonia axyridis Pall. (Col., Coccinellidae): rapidly obtaining fecund adults or in dormancy. J Appl Entomol 117:314-317

Pell JK, Baverstock J, Roy HE, Ware RL, Majerus MEN (2008) Intraguild predation involving Harmonia axyridis: a review of current knowledge and future perspectives. BioControl 53:147-168

Phoofolo MW, Obrycki JJ (1995) Comparative life-history studies of Nearctic and Palearctic populations of Coccinella septempunctata (Coleoptera: Coccinellidae). Environ Entomol 24:581-587

Sakurai H, Hirano T, Takeda S (1986) Physiological distinction between estivation and hibernation in the lady beetle, Coccinella septempunctata brucki (Coleoptera, Coccinellidae). Appl Entomol Zool 21:424-429

Sakurai H, Kawai T, Takeda S (1992) Physiological changes related to diapause of the lady beetle, Harmonia axyridis (Coleoptera: Coccinellidae). Appl Entomol Zool 27:479-487

Sakurai H, Kumada Y, Takeda S (1993) Seasonal prevalence and hibernating diapause behaviour in the lady beetle, Harmonia axyridis. Res Bull Fac Agric Gifu Univ. 51-55

Sakuratani Y, Matsumoto Y, Oka M, Kubo T, Fujii A, Uotani M, Teraguchi T (2000) Life history of Adalia bipunctata (Coleoptera: Coccinellidae) in Japan. Eur J Entomol 97:555-558

Schanderl H, Ferran A, Larroque MM (1985) The trophic and thermal requirements of larvae of the coccinellid Harmonia axyridis Pallas. Agronomie 5:417-421

Schanderl H, Ferran A, Garcia V (1988) Rearing two coccinellids Harmonia axyridis and Semiadalia undecimnotata on eggs of Anagasta kuehniella killed with ultraviolet radiation. Entomol Exp Appl 49:235-244

Seko T, Miura K (2009) Effects of artificial selection for reduced flight ability on survival rate and fecundity of Harmonia axyridis (Pallas) (Coleoptera: Coccinellidae). Appl Entomol Zool 44:587-594

Soares AO, Coderre D, Schanderl H (2003) Effect of temperature and intraspecific allometry on predation by two phenotypes of Harmonia axyridis Pallas (Coleoptera: Coccinellidae). Environ Entomol 32:939-944

Stathas GJ, Eliopoulos PA, Kontodimas DC, Giannopapas J (2001) Parameters of reproductive activity in females of Harmonia axyridis (Coleoptera: Coccinellidae). Eur J Entomol 98:547-549

Tanagishi K (1976) Hibernation of the ladybeetle Harmonia axyridis. Insectarium 13:294-298

Tauber MJ, Tauber CA, Masaki S (1986) Seasonal adaptations of insects. Oxford University Press, New York

Tedders WL, Schaefer PW (1994) Release and establishment of Harmonia axyridis (Coleoptera: Coccinellidae) in the southeastern United States. Entomol News 105:228-243

van Lenteren JC, Loomans AJM, Babendreier D, Bigler F (2008) Harmonia axyridis: an environmental risk assessment for Northwest Europe. BioControl 53:37-54

Verheggen FJ, Fagel Q, Heuskin S, Lognay G, Francis F, Haubruge E (2007) Electrophysiological and behavioral responses of the multicolored Asian lady beetle, Harmonia axyridis Pallas, to sesquiterpene semiochemicals. J Chem Ecol 33:2148-2155

Waarneming.nl (2010) Field survey in the Netherlands by general public. In: Stichting Natuurinformatie. http://waarneming. nl/soortenlijst.php?diergroep=1 Accessed: 22 December 2010 
Wang H, Ji S, Zhai W (2009) Effect of temperature on survival, development and fecundity of Harmonia axyridis. Chin Bull Entomol 46:449-452

Wang S, Michaud JP, Tan XL, Zhang F, Guo XJ (2011) The aggregation behavior of Harmonia axyridis in its native range in Northeast China. BioControl 56:193-206

Xia JY, Van der Werf W, Rabbinge R (1999) Temperature and prey density on bionomics of Coccinella septempunctata (Coleoptera: Coccinellidae) feeding on Aphis gossypii (Homoptera: Aphididae) on cotton. Environ Entomol 28:307-314

Yano E, Jiang N, Hemerik L, Mochizuki M, Mitsunaga T, Shimoda T (2005) Time allocation of Orius sauteri in attacking Thrips palmi on an eggplant leaf. Entomol Exp Appl 117:177-184

\section{Author Biographies}

C. L. Raak-van den Berg performed this study as part of her $\mathrm{PhD}$ project focussing on life history characteristics of Harmonia axyridis and how these explain its successful establishment and spread in Europe.
Lia Hemerik is a mathematical biologist whose current work focuses on the application of Cox's regression model and modelling population dynamical processes in behavioural ecology, conservation biology, aquatic ecology or soil biology.

Peter W. de Jong studies the adaptation of insects, especially in a multitrophic context, focussing in particular on the mechanisms responsible for observed geographical and temporal patterns in the distribution of adaptations.

Joop C. van Lenteren works on behavioural ecology and population dynamics of parasitoids, theoretical and practical aspects of biological control, IPM and sustainable crop production, and anatomy and sensory physiology of parasitoid ovipositors. 